\title{
Abscesso piogênico do fígado e esquistossomose mansoni
}

Pyogenic liver abscess and schistosomiasis mansoni

\author{
José Roberto Lambertucci', Mário Richard-Lima ${ }^{2}$ e José Carlos Serufo ${ }^{1}$
}

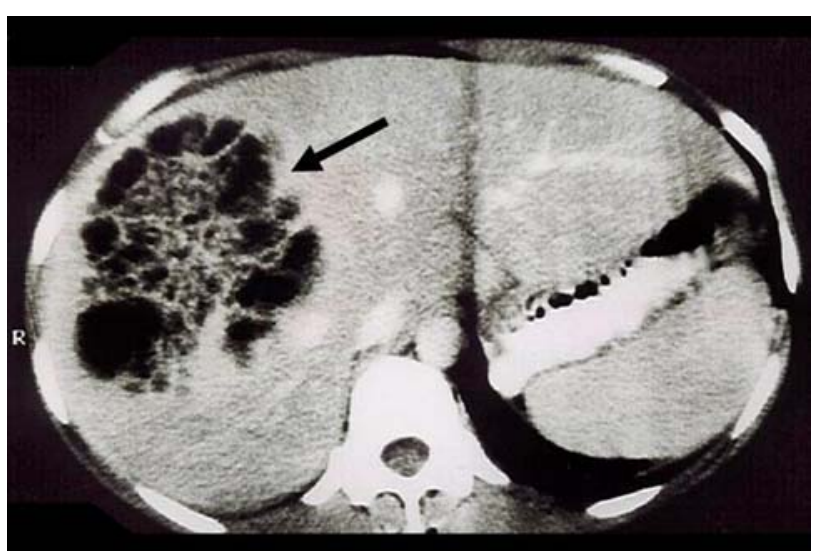

A

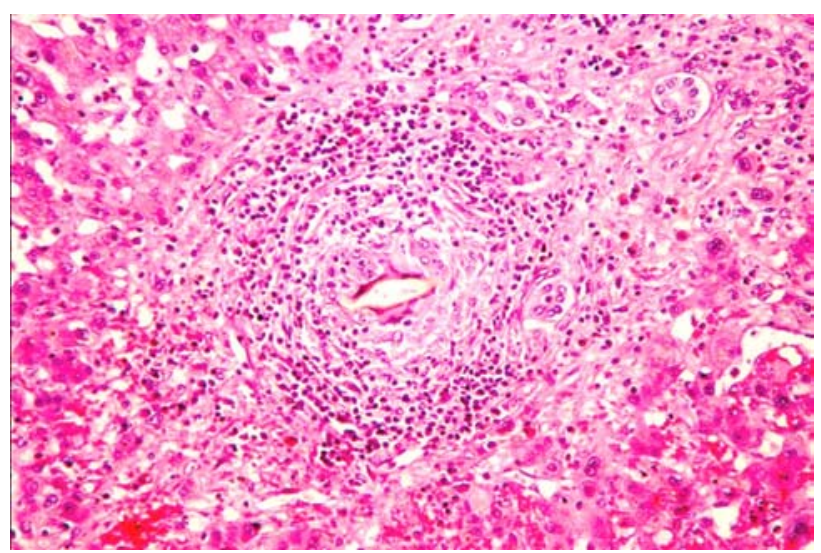

B

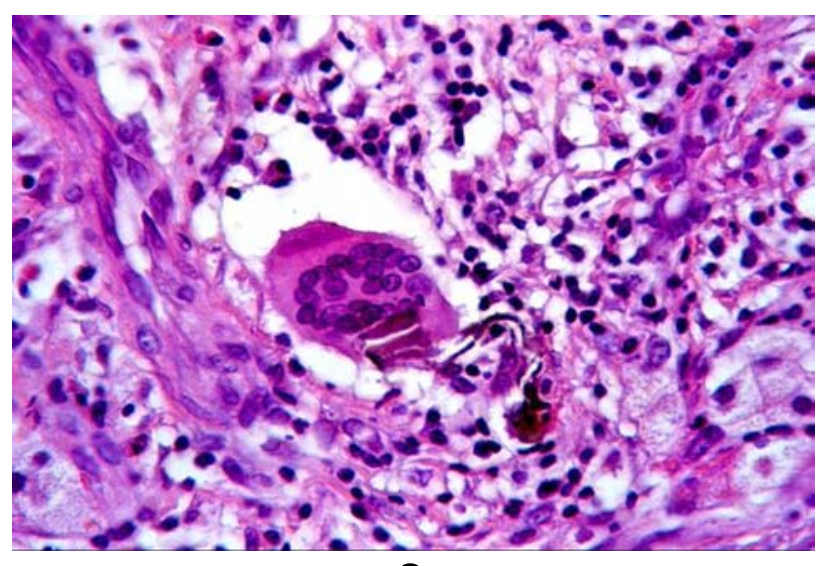

C

1. Serviço de Doenças Infecciosas e Parasitárias do Departamento de Clínica Médica da Universidade Federal de Minas Gerais, Belo Horizonte, MG. 2. Departamento de Anatomia Patológica da Faculdade de Medicina da Universidade Federal de Minas Gerais, Belo Horizonte, MG.

Endereço para correspondência: Prof. José Roberto Lambertucci. Dept ${ }^{\circ}$ de Clínica Médica/FM/UFMG. Av. Alfredo Balena 190, 30130-100 Belo Horizonte, MG, Brasil.

Telefax: $55313248-9820$

Recebido para publicação em 20/9/2001. 
A paciente, de 37 anos de idade, procurou o hospital com história de febre, fadiga, vômitos e dor abdominal, de início há 5 dias. Havia história de histerectomia há um ano realizada em decorrência de aborto espontâneo e suas complicações. Recebeu tratamento para esquistossomose 10 anos antes da internação atual. A paciente aparentava estar aguda e gravemente enferma. O hemograma revelou anemia discreta e o leucograma mostrava leucocitose com desvio à esquerda. Palpouse o fígado a $5 \mathrm{~cm}$ do RCD. A telerradiografia de tórax confirmou a presença de derrame pleural em base direita e o ultra-som de abdomen identificou massa heterogênea no lobo direito do fígado sugestiva de abscesso hepático. A tomografia computadorizada do abdomen confirmou o diagnóstico de abscesso hepático; não era possível excluir, entretanto, a presença de neoplasia associada (Figura A: nota-se grande massa loculada - seta - em lobo direito do fígado). Três hemoculturas e a cultura de secreção obtida por punção biópsia do fígado guiada pelo ultra-som resultaram negativas. Três exames de fezes e uma biópsia retal não revelaram ovos de Schistosoma mansoni. As biópsias hepáticas, realizadas durante a laparotomia, não mostraram sinais de malignidade, confirmaram o diagnóstico de abscesso piogênico e revelaram granulomas esquistossomóticos no fígado (Figura B: note o típico granuloma circundando um ovo de $S$. mansoni; coloração H\&E; X400; Figura C: célula multinucleada fagocitando a casca de um ovo de $S$. mansoni; H\&E; X1000). Não se isolaram bactérias na secreção obtida durante a cirurgia. A paciente recebeu antibióticos (oxacilina, gentamicina e metronidazol) e praziquantel para esquistossomose com boa resposta clínica. No acompanhamento, em ambulatório, observou-se regressão completa da lesão hepática.
A 37 years old woman was admitted to hospital with a 5-day hystory of fever, fatigue, vomiting and abdominal pain. One year before she was operated on (hysterectomy) because of persistent gynecological bleeding after having a spontaneous abortion and its complications. She also reported treatment for schistosomiasis at age 27. She looked acutely and severely ill. A discrete anemia was diagnosed in a routine hemogram; there was also leucocytosis with a left shift. A tender right liver lobe was palpable $5 \mathrm{~cm}$ below the right costal margin. A chest $\mathrm{x}$-ray disclosed pleural effusion on the right side. Abdominal ultrasound showed a heterogeneous mass in the right lobe of the liver, compatible with liver abscess. Computed tomography of the abdomen confirmed the presence of liver abscess; the diagnosis of associated neoplasia though could not be excluded (Figure A: note the large loculated mass arrow - in the liver). Three hemocultures and culture of the material obtained by liver biopsy grew no organisms. Three stool examinations and a rectal biopsy did not find eggs of Schistosoma mansoni. She was submitted to laparotomy to try and drain the abscess, and liver biopsies were taken during surgery. Analysis of the fragments of liver showed granulomas around $S$. mansoni eggs (Figure B: note the typical granuloma of $S$. mansoni; stained by hematoxylin and eosin; X400) (Figure C: there is a multinucleated cell phagocytosing an egg shell; hematoxylin and eosin; X1000). No bacteria was isolated from the material obtained by liver byopsy. She was treated with antibiotics (gentamicin, oxacillin, metronidazol) and praziquantel for schistosomiasis and presented a good clinical response. In the follow up, at the outpatient clinic, complete regression of the hepatic lesion was observed.

\section{REFERÊNCIAS BIBLIOGRÁFICAS}

1. Lambertucci JR, Rayes AA, Serufo JC, Nobre V. Pyogenic abscesses and parasitic diseases. Revista do Instituto de Medicina Tropical de São Paulo 43: 67-74, 2001.

2. Lambertucci JR, Teixeira R, Navarro MM, Coelho PM, Ferreira MD. Liver abscess and schistosomiasis: a new association. Revista da Sociedade Brasileira de Medicina Tropical 23: 239-240, 1990.
3. Teixeira R, Coelho PM, Brasileiro Filho G, Serufo JC, Pfeilsticker FJ, Santa Cecilia G, Lambertucci JR. Pathogenic aspects of pyogenic liver abscess associated with experimental schistosomiasis. American Journal of Tropical Medicine and Hygiene 64: 298-302, 2001. 